\title{
KAJIAN PERSEPSI KONSUMEN TERHADAP MINYAK GORENG SAWIT MERAH UNTUK MENUNJANG SISTEM PEMASARAN
}

\author{
Oleh
}

\author{
Inna Sri Supina Adi dan Sri Hidajati Ramdani \\ Dosen Fakultas Ekonomi Universitas Pakuan
}

\begin{abstract}
ABSTRAK
Bahan-bahan aktif yang terdapat di dalam minyak sawit dari kelompok tokoferol dan karotenoida yang berwarna merah sangat sensitif terhadap suhu tinggi dan oksidator, sehingga pengolahan minyak sawit yang baik perlu mempertahankan komponen aktif tersebut. Oleh sebab itu, teknologi pengolahan CPO yang menghasilkan minyak sawit merah merupakan teknologi penyediaan minyak goreng yang paling tepat. Selama ini yang terjadi justru sebaliknya. Minyak dianggap baik dan sehat jika warna jernih. Padahal untuk menghasilkan warna jernih, yang berarti membuang komponen aktif yang bermanfaat untuk mencegah avitaminosis, penyakit darah tinggi, jantung koroner dan kanker dibutuhkan biaya yang tidak sedikit. Melihat bahan-bahan aktif dalam minyak sawit, yang sangat bermanfaat bagi kesehatan tetapi dibuang percuma, teknologi pengolahan minyak sawit perlu diubah dalam bentuk minyak sawit merah untuk mempertahankan bahan aktif tersebut. Namun upaya ini perlu didukung dengan sosialisasi dan promosi yang terus menerus tentang manfaat minyak sawit merah bagi kesehatan, setelah diketahui dengan jelas pandangan masyarakat terhadap minyak sawit merah. Keberhasilan sosialisasi dan promosi tersebut tergantung pada pengetahuan mengenai persepsi konsumen mengenai minyak sawit merah sebagai dasar penyusunan strategi sosialisasi dan promosi. Penelitian ini bertujuan untuk mengetahui persepsi konsumen tersebut.
\end{abstract}


Metode yang digunakan dalam penelitian ini adalah metode sampling untuk memperoleh gambaran yang jelas mengenai objek yang diteliti. Materi yang disurvei adalah data umum responden, perilaku dan persepsi konsumen. Lokasi penelitian untuk penyebaran kuesioner adalah 5 (lima) pasar (tradisional) yang ada di wilayah kota Bogor.

Hasil penelitian menunjukkan (1) masyarakat kurang paham mengenai minyak goreng sawit merah, hanya $28 \%$ dari responden yang paham, (2) industri minyak goreng berada dalam pasar bersaing, dengan leader Bimoli, (3) preferensi masyarakat terhadap minyak goreng secara umum terutama terletak pada atribut kualitas (terkait proses produksi yang 'higienis'), kandungan nutrisi dan harga, (4) persepsi masyarakat terhadap hasil olahan dengan menggunakan minyak goreng sawit merah menunjukkan tidak penting. Hal yang penting bagi masyarakat adalah kualitas dan kandungan gizi minyak goreng, (5) persepsi dan sikap masyarakat terhadap minyak goreng sawit merah memperoleh skala Fischbein dalam pentil pertama, berada pada tahap perkenalan siklus hidup produk.

Diperlukan strategi pemasaran yang bersifat promosi dan sebaiknya yang diambil adalah yang bersifat informasi dan mendidik yaitu sosialisasi. Topik yang dikemukakan sebaiknya terkait dengan kandungan dan proses produksi. Media yang diambil sebaiknya pada rubrik ilmu pengetahuan atau kesehatan berbentuk iklan layanan umum dengan frekuensi tinggi.

Kata kunci : minyak sawit merah, tokorerol, tokotrienol, karotenoid, persepsi konsumen, promosi, sosialisasi.

\section{PENDAHULUAN}

\subsection{Latar Belakang Penelitian}

Minyak sawit merah mulai diproduksi di Indonesia sekitar 10 tahun lalu. Namun, sampai saat ini belum banyak dijumpai produk minyak sawit merah di pasaran. Hal ini menimbulkan dugaan bahwa masyarakat pada umumnya belum mengenal minyak sawit merah, apalagi menggunakannya untuk 
konsumsi sehari-hari. Di sisi lain, minyak goreng yang berasal dari minyak sawit yang dibuat dengan teknologi lama/konvensional merusak bahan-bahan aktif alami yang sangat bermanfaat bagi kesehatan dan menggantikannya dengan bahan aditif sintetik hanya untuk mendapatkan minyak goreng dengan penampilan yang jernih. Dengan teknologi baru pengolahan minyak sawit menjadi minyak goreng yang berwarna merah, bahan-bahan aktif alami dalam minyak sawit dapat dipertahankan.

Bahan-bahan aktif yang terdapat di dalam minyak sawit dari kelompok tokoferol dan karotenoida yang berwarna merah sangat sensitif terhadap suhu tinggi dan oksidator, sehingga pengolahan minyak sawit yang baik perlu mempertahankan komponen aktif tersebut (Muchtadi, 1998). Oleh sebab itu teknologi pengolahan CPO menghasilkan minyak sawit merah merupakan teknologi penyediaan minyak goreng yang paling tepat. Selama ini yang terjadi justru sebaliknya. Minyak dianggap baik dan sehat jika warnanya jernih. Padahal untuk menghasilkan warna jernih, yang berarti membuang komponen aktif yang bermanfaat untuk mencegah avitaminosis, penyakit darah tinggi, jantung koroner dan kanker (Adnan, 1991; Muhilal, 1991; Iwashaki \& Murokoshi, 1992), dibutuhkan biaya yang tidak sedikit.

Sebagai antioksidan, karotenoida dapat mencegah proses oksidasi minyak sehingga pada penggorengan tidak mudah muncul radikal bebas akibat pemanasan. Hasil penelitian menunjukkan bahwa penggunaan minyak sawit merah pada penggorengan empat kali baru hilang kandungan karotennya, baik karena terserap oleh produk yang dfigoreng maupun akibat pemanasan (Puspitasari et al., 1998), sedangkan penggunaan minyak goreng biasa yang jernih untuk penggorengan tiga kali kemungkinan telah menghasilkan radikal bebas, karena radikal bebas dapat terbentuk pada pemanasan minyak goreng pada $215^{\circ} \mathrm{C}$ selama 15 menit (http://www.keepwell.com/frying.htm). Penyerapan karoten oleh bahan makanan yang digoreng akan memberikan tambahan gizi tokoferol dan karoten. Rasa makanan yang digoreng dengan minyak sawit merah yang telah digunakan empat kali juga tidak menghasilkan perbedaan rasa 
dibandingkan menggunakan minyak segar (Puspitasari et al., 1998).

Minyak sawit merah juga bermanfaat sebagai sumber B -karoten jika digunakan sebagai shortening pada pembuatan cookies. Kebutuhan vitamin A bagi anak sekolah dapat tercukupi dengan konsumsi 65-100 g cookies minyak sawit merah per hari dengan kandungan ? -karoten 562-1010 RE/ 100g cookies (Rimbawan \& Damayanti, 1998). Bahan aktif yang tidak kalah penting adalah tokotrienol. Bahan aktif ini berperan sebagai agen yang dapat menurunkan kolesterol, karena dapat menurunkan jumlah fraksi lipoprotein densitas rendah pada darah (LDL-kolesterol) serta menurunkan tingkat total serum kolesterol. Dengan demikian, senyawa ini berperan dalam meningkatkan perbandingan fraksi HDL/LDL, yaitu perbandingan lipoprotein densitas tinggi (HDL- kolesterol) terhadap LDL-kolesterol. Aktivitas ini sangat membantu dalam menurunkan resiko serangan jantung (Gordon, 1977).

Melihat bahan-bahan aktif dalam minyak sawit yang sangat bermanfaat bagi kesehatan tetapi dibuang percuma, teknologi pengolahan minyak sawit perlu diubah dalam bentuk minyak sawit merah untuk mempertahankan bahan aktif tersebut. Namun upaya ini perlu didukung dengan sosialisasi dan promosi yang terus-menerus tentang manfaat minyak sawit merah bagi kesehatan, setelah diketahui dengan jelas pandangan masyarakat terhadap minyak sawit merah, yang bahkan mungkin masih asing bagi kebanyakan masyarakat awam.

\subsection{Perumusan Masalah}

Beberapa masalah yang diduga muncul dalam pemasaran minyak sawit merah adalah:

1. Adanya bahan aktif alami dan fungsinya bagi kesehatan yang belum diketahui secara luas

2. Adanya bahan sintetik yang tidak sehat di dalam minyak goreng

3. Promosi yang menyesatkan bahwa minyak yang jernih identik dengan minyak yang menyehatkan 
4. Kekhawatiran adanya bahan pengotor atau minyak bekas (jelantah) pada minyak goreng yang berwarna gelap yang akan berpengaruh pada rasa produk/hasil gorengan

5. Konsumen masih merasa asing dengan minyak goreng jenis baru ini.

Jika dugaan ini benar, yang perlu dibuktikan dengan suatu survey yang akurat, alternatif solusinya melalui beberapa upaya antara lain:

1. Sosialisasi minyak sawit merah dengan kandungan bahan aktif alami yang banyak manfaatnya bagi kesehatan

2. Standardisasi dan labelilasi jaminan mutu minyak sawit merah

3. Harga minyak sawit merah yang kompetitif sebagai daya tarik bagi konsumen, yang diskonnya diambil dari penurunan biaya produksi akibat penggunaan teknologi baru tanpa adanya biaya untuk bleaching dan lain-lain

4. Subsidi pemerintah dari pengalihan beban impor karotenoida dan suplemen vitamin A

\subsection{Tujuan Penelitian}

Penelitian ini bertujuan untuk :

1. Mengetahui sejauh mana pemahaman masyarakat tentang minyak sawit merah dan bahan-bahan aktif alami yang terkandung di dalamnya yang berasal dari minyak sawit mentah

2. Mengetahui secara umum industri minyak goreng

3. Mengetahui preferensi masyarakat terhadap minyak goreng yang ada di pasaran, kriteria minyak goreng seperti apa yang dikehendaki (mutu, harga, rasa, tampilan/kejernihan, keawetan, dan kriteria lainnya)

4. Mengetahui tentang kemungkinan respon masyarakat jika ada minyak goreng dengan spesifikasi yang berbeda dengan minyak goreng yang telah beredar luas selama ini

5. Mengetahui persepsi masyarakat jika hasil gorengan dengan minyak sawit merah tampak merah 
kekuningan, tidak seperti hasil penggorengan dengan minyak goreng biasa

6. Merumuskan strategi pemasaran minyak sawit merah

\subsection{Manfaat Penelitian}

1. Berdasarkan hasil penelitian ini diharapkan dapat diperoleh bahan rekomendasi strategi pemasaran minyak sawit merah berdasarkan persepsi konsumen.

2. Penghematan devisa dalam bentuk pengurangan impor bahan aktif antioksidan (karoteniod, tokotrienol dan lain lain) dan biaya pengolahan minyak goreng dalam bentuk minyak sawit merah yang kaya bahan aktif bermanfaat.

3. Dalam jangka panjang, keberhasilan pemasaran minyak sawit merah akan meningkatkan status kesehatan masyarakat.

\section{TINJAUAN PUSTAKA}

\subsection{Teknologi Refinery Konvensional Versus Minyak Sawit Merah}

Minyak sawit merupakan minyak nabati yang paling

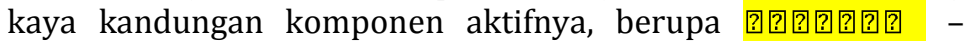
karoten, serta antioksidan tokoferol dan tokotrienol (Gambar 1), dibandingkan minyak nabati lainnya seperti minyak kelapa, dan minyak yang berasal dari biji-bijian seperti jagung, kedelai, biji bunga matahari, kacang tanah, dan rape-seed (canola). Bahanbahan aktif tersebut dihilangkan melalui proses bleaching menggunakan bleaching earth disertai pemanasan. Hal ini disebabkan standar minyak goreng yang berlaku di seluruh dunia saat ini masih berkiblat pada minyak goreng dari bahan baku non sawit, sehingga diutamakan kejernihannya. Pada standar tersebut minyak goreng memiliki standar warna merah maksimal 2,0 Lovibond unit (Rossell, 2008). Dengan demikian, untuk mencapai baku mutu minyak goreng tersebut, kandungan bahan-bahan aktif yang bernilai tinggi dalam minyak sawit harus dihilangkan. Akibatnya, minyak yang dihasilkan tidak lagi mengandung bahan antioksidan alami dan sebagai gantinya 
digunakan antioksidan sintetik BHA (Butylated Hidroxy Anisol) untuk meningkatkan daya tahan minyak terhadap oksidasi sehingga minyak tidak mudah tengik. Oleh sebab itu diperlukan inovasi teknologi agar komponen alami yang sangat bermanfaat bagi kesehatan tersebut dapat dipertahankan (Bakrie, 1998).

Pembuatan minyak goreng dalam bentuk minyak sawit merah dapat mempertahankan 85persen bahan-bahan aktif dalam minyak sawit. Dengan teknologi ini dapat dihemat trilyunan rupiah ditinjau dari nilai bahan aktif yang dapat diselamatkan. Jika o-karoten komersial dipasarkan dalam bentuk larutan karoten 30persen yang dipasarkan dengan harga US\$ 200/ kg atau setara dengan Rp 6,2 juta/ kg karoten murni dengan asumsi nilai 1 US\$ = Rp 9.300,00. Saat ini Indonesia sebagai produsen terbesar di dunia memproduksi sekitar 16 juta ton CPO per tahun, sekitar 69,75persen ( 11,16 juta ton) digunakan untuk konsumsi dalam negeri (Maulida, 2007) antara lain untuk kebutuhan pangan dalam bentuk minyak goreng, margarine, dan shortening.

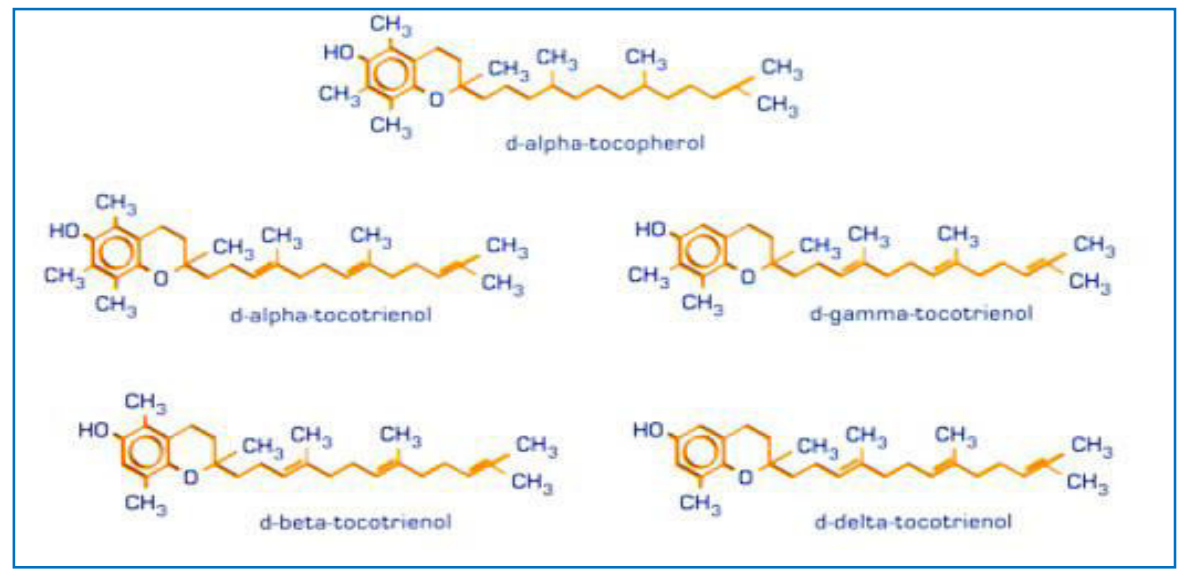

Gambar 1.

Struktur Senyawa Tokoferol Dan Tokotrienol Yang Merupakan Bahan Aktif Penting Di Dalam Minyak Sawit 


\subsection{Persepsi Konsumen}

Persepsi adalah proses di mana seseorang memberikan arti terhadap lingkungan yang melibatkan pengorganisasian dan menginterpretasikan berbagai stimulus ke dalam aspek psikologis (Gibson, Ivancevich, Donnely, 1994). Perilaku konsumen yang berkaitan dengan keputusan pembelian terhadap suatu produk, diawali dengan proses pengenalan kebutuhan. Setelah proses ini dilalui, selanjutnya konsumen akan memasuki proses pencarian informasi untuk memenuhi kebutuhannya. Dalam proses pencarian informasi ini kemampuan konsumen dalam mengingat kembali informasi tentang suatu produk mempunyai peranan penting. Kemampuan mengingat suatu produk yang baik oleh konsumen berkaitan dengan preferensi terhadap atribut-atribut dari produk yang dianggap sesuai dengan keinginan konsumen. Preferensi terhadap atribut suatu produk didasarkan atas persepsi konsumen sebelumnya terhadap atribut produk tersebut.Berdasarkan persepsi ini konsumen akan mempunyai sikap tertentu terhadap produk yang dapat berupa sikap positif atau sikap yang negatif.

Pengertian sikap menurut Gibson (1994) adalah sebagai sikap kesiapan mental bagi timbulnya suatu kebutuhan. Sedangkan perilaku didefinisikan sebagai suatu bentuk tindakan yang dihasilkan dari suatu sikap. Menurut Guiltiman (1990), sikap (attitude) adalah perasaan, evaluasi dan kecenderungan untuk bereaksi terhadap objek atau gagasan sedangkan menurut Engel (1993) dalam bukunya Consumer Behavior mendefinisikan sikap atau attitude sebagai suatu evaluasi yang menyeluruh yang memungkinkan seseorang untuk merespon suka atau tidak suka terhadap objek yang diberikan. Sikap biasanya memainkan peran penting dalam membentuk perilaku (behavior). Sikap yang telah terbentuk sebelumnya terhadap suatu produk, yang selanjutnya akan membentuk perilaku konsumen yang berkaitan dengan keputusan pembelian suatu produk.

Persepsi dan sikap konsumen yang positif akan mendorong perilaku konsumen dalam membentuk keputusan untuk membeli dan mengkonsumsi suatu produk. Adanya 
persepsi dan sikap yang positif terhadap atribut produk dapat menyebabkan derajat kepentingan dari suatu atribut berbeda dengan atribut lainnya sehingga bermanfaat bagi produsen dalam mengetahui atribut-atribut pokok yang paling penting menurut konsumennya.

\subsection{Riset Perilaku Konsumen}

Konsumen adalah seorang manusia, maka ia cenderung mempunyai keinginan tidak terbatas, dengan variasi keinginan akan barang yang tidak terhingga, dan dengan kepribadian dan tingkah laku yang berbeda pula. Secara praktis, perilaku konsumen dalam mengkonsumsi barang dan jasa dipengaruhi oleh 2 (dua) faktor dasar, di mana kedua faktor ini secara bersama-sama akan mempengaruhi perilaku beli konsumen walaupun tetap tidak bisa diketahui secara tepat apa yang sebenarnya menentukan seseorang membeli sesuatu. Adapun faktor-faktor dasar tersebut yaitu :

1) Faktor Eksternal yang terdapat di luar diri konsumen seperti kebudayaan, kelas sosial, kelompok referensi dsb.

2) Faktor Internal yang terdapat di dalam diri konsumen seperti persepsi, pembelajaran, sikap, motivasi, konsep diri, dsb.

Dalam kegiatan perilaku konsumen, riset tentang sikap (attitude) konsumen adalah salah satu jenis riset yang paling banyak dilakukan. Hal ini disebabkan karena sikap seseorang (yang secara praktis berarti pernah suka atau tidak suka terhadap sesuatu) dianggap paling dekat dengan perilaku seseorang. Jika seseorang mempunyai sikap suka terhadap suatu produk, ia akan cenderung berusaha mengkonsumsi produk tersebut, dan sebaliknya bila ia mempunyai sikap tidak suka.

\subsection{Model Sikap dan Perilaku Konsumen dari FISCHBEIN}

Salah satu model sikap yang terkenal adalah model sikap multiatribut dari FISCHBEIN. Mengutip dari Mowen (1993) dalam Husein Umar (2000) dalam buku "Riset Pemasaran dan Perilaku Konsumen"; model sikap FISCHBEIN 
ini berfokus pada prediksi sikap yang dibentuk seseorang terhadap obyek tertentu.

Model ini mengindentifikasi tiga faktor utama untuk memprediksi sikap, yaitu:

1) Faktor pertama adalah keyakinan seseorang terhadap atribut obyek yang menonjol.

2) Faktor kedua adalah kekuatan keyakinan seseorang bahwa atribut memiliki kekhasan, biasanya diketahui dalam bentuk pertanyaan. Misalnya seberapa setuju bahwa obyek $\mathrm{X}$ memiliki atribut $\mathrm{Y}$.

3) Faktor ketiga adalah evaluasi dari masing-masing keyakinan akan atribut yang menonjol, dimana diukur seberapa baik atau tidak baik keyakinan mereka terhadap atribut-atribut itu.

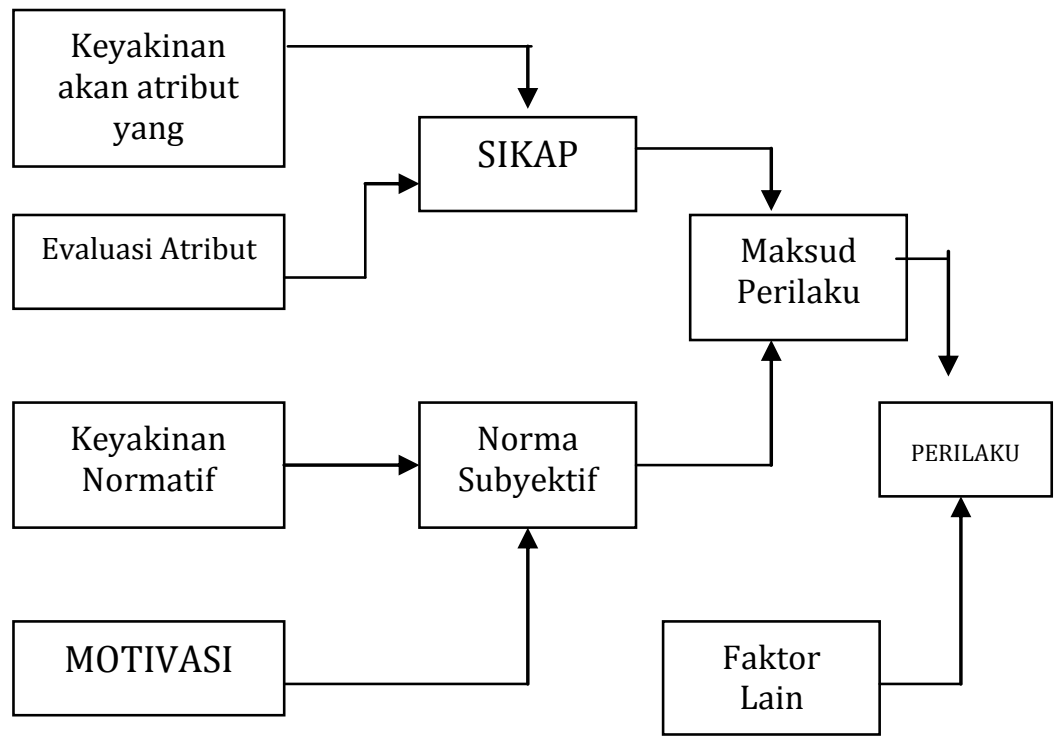

Gambar 2.

Hubungan antara Komponen dalam Model Fischbein 
Model sikap Fischbein pada prinsipnya menghitung Ao (Attitude Toward The Object); yaitu sikap seseorang terhadap "sebuah obyek yang dikenali lewat atribut-atribut yang melekat pada obyek tersebut". Bila seseorang melihat, meraba, mencoba atau menggunakan produk untuk sekian waktu lamanya maka akan timbul Sikap-sikap sesorang seperti kecewa $(-)$, senang $(+)$, loyal (+). Mengapa konsumen menjadi senang atau kecewa, karena sebelumnya ia mempunyai harapan-harapan terhadap suatu obyek yang kemudian ia akan menilai apakah obyek tersebut sesuai dengan harapannya.

Model pengukuran sikap Fischbein ini digunakan agar diperoleh konsistensi antara sikap dan perilakunya, sehingga model Fischbein ini memiliki 2 (dua) komponen penting yaitu komponen sikap dan komponen norma subyektif.

a. Komponen Sikap. Komponen ini bersifat internal individu, berkaitan langsung dengan obyek penelitian dan atribut-atribut langsungnya yang memiliki peranan penting dalam pengukuran perilaku, karnea akan menentukan tindakan apa yang akan dilakukan, tanpa dipengaruhi faktor eksternal.

b. Komponen Norma Subyektif. Komponen ini bersifat eksternal individu yang mempunyai pengaruh terhadap perilaku individu. Komponen ini dapat dihitung dengan cara mengkalikan nilai kepercayaan normatif individu terhadap atribut dengan motivasi untuk untuk menyetujui atribut tersebut. Kepercayaan normatif menyangkut kuatnya keyakinan terhadap atribut yang ditawarkan sehingga mempengaruhi perilakunya terhadap obyek. Sedangkan motivasi menyetujui merupakan sikap terhadap atribut yang ditawarkan sebagai faktor yang mempengaruhi perilakunya.

Pengukuran sikap dapat dilihat dari "atribut" produk, seperti kualitas (tahan lama, enak, kualitas bahan, etc), model (desain, trendi), warna (menarik), harga (sesuai dengan 
kualitas, dibandingkan dengan merek lain). Langkah untuk menghitung sikap terhadap produk:

1) Menentukan salient belief atribut yang dianggap relevan atau penting yang ditanyakan kepada konsumen (responden). Setiap produk mempunyai banyak atribut dan semuanya bisa menentukan sikap seseorang.

2) Membuat pertanyaan untuk mengukur belief. Setelah atribut ditentukan, konsumen akan ditanya bagaimana keyakinan (belief) terhadap atribut tersebut. Isi pertanyaan diusahakan utnuk mengukur "keyakinan seseorang terhadap atribut obyek".

Trend pengukuran :

1 = sangat tidak setuju/sangat tidak penting

2 = tidak setuju / tidak penting

$3=$ netral

$4=$ setuju / penting

5 = sangat setuju / sangat penting.

3) Membuat pertanyaan untuk mengukur EVALUATION. Sama seperti pertanyaan "belief", konsumen ditanya bagaimana evaluasi konsumen terhadap atribut yang telah diukur belief-nya, apakah penting atau tidak penting. Perhatikan di dalam mengukur EVALUASI tidak disebut merek tertentu namun menyebut produk secara generik atau umum.

4) Mengukur sikap terhadap produk. Pengukuran sikap dilakukan dengan mengukur keseluruhan atribut (multiatribut) dengan rumus :

$$
\text { Ao }=\Sigma(\text { bi) (ei) }
$$

di mana

Ao $=\quad$ sikap total konsumen terhadap produk tertentu.

$\mathrm{bi}=\quad$ kekuatan keyakinan konsumen terhadap atribut $\mathrm{i}$ dari produk "sebelum ia membeli atau menggunakannya".

ei $=\quad$ evaluasi kepercayaan konsumen terhadap atribut i dari produk secara umum, tanpa dikaitkan dengan merek tertentu. $\Sigma=$ penjumlahan dari sejumlah kriteria atribut i yang relevan. 
Untuk data yang dibutuhkan untuk menganalisis suatu permasalahan adalah :

- Variabel Keyakinan Membeli (merupakan tanggapan sebelum membeli). Komponen-komponen dari variabel ini misalnya desain yang menarik, ukuran produk, warna, kemasan, rasa sesuai dengan selera, manfaat produk, gengsi.

- Variabel Evaluasi (merupakan tanggapan setelah mengkonsumsi), di mana komponen-komponen ini harus sama dengan komponen variabel keyakinan membeli.

- Variabel Keyakinan Normatif (merupakan pengaruh orang lain terhadap konsumen dalam membeli produk). Komponen-komponen dari variabel ini misalnya anggota keluarga, orang lain, teman, tenaga penjual.

- Motivasi (motivasi membeli atas pengaruh orang lain). Komponen-komponen ini harus sama dengan komponen variabel keyakinan normatif.

Pemakaian model FISCHBEIN hendaknya berasumsi bahwa konsumen menggunakan pendekatan "standar hirarki efek" seperti AIDCA atau AIDA. Minat konsumen potensial atas suatu produk yang ditawarkan di pasar, pada dasarnya terbagi atas tiga tahapan; yaitu tahap mengetahui, terpengaruh, dan bertindak untuk melakukan pembelian. Model-model untuk tahapan-tahapan ini adalah model AIDCA (Attention, Interest, Desire, Conviction, Action), AIDA (Attention, Interest, Desire, Action), Hierarchy of Effects, dan model Adopsi Inovasi (Butler and Fischbeck, 2007)

Tabel 1

Model-model Minat Konsumen Potensial

\begin{tabular}{|l|l|l|l|l|}
\hline \multirow{2}{*}{$\begin{array}{c}\text { Tahap-tahap } \\
\text { Minat }\end{array}$} & \multicolumn{1}{|c|}{ AIDCA } & \multicolumn{1}{|c|}{ AIDA } & $\begin{array}{c}\text { Hierarchy } \\
\text { of Effects }\end{array}$ & $\begin{array}{c}\text { Adopsi } \\
\text { Inovasi }\end{array}$ \\
\cline { 2 - 5 } & Menyadari & Menyadari & $\begin{array}{l}\text { Menyadari } \\
\text { Mengetahui }\end{array}$ & Menyadari \\
\hline Mengetahui & $\begin{array}{l}\text { Perhatian } \\
\text { Minat }\end{array}$ & $\begin{array}{l}\text { Perhatian } \\
\text { Minat }\end{array}$ & $\begin{array}{l}\text { Menyukai } \\
\text { Preferensi }\end{array}$ & $\begin{array}{l}\text { Perhatian } \\
\text { Penilaian }\end{array}$ \\
\hline Tindakan & $\begin{array}{l}\text { Keyakinan } \\
\text { Pembelian }\end{array}$ & Tindakan & $\begin{array}{l}\text { Keyakinan } \\
\text { Pembelian }\end{array}$ & $\begin{array}{l}\text { Mencoba } \\
\text { Adopsi }\end{array}$ \\
\hline
\end{tabular}




\subsection{Siklus Hidup Produk}

Setiap produk biasanya mengalami kelahiran dan kematian baik dalam jangka pendek maupun jangka panjang. Suatu produk bisa saja pada suatu waktu sangat disukai banyak orang dan laku keras, namun di lain waktu produk itu tidak laku lagi dijual. Jadi pengertian siklus hidup produk yaitu tahapan suatu produk mulai dari lahir, tumbuh, dewasa dan mati.

\section{Product Life Cycle Curve}

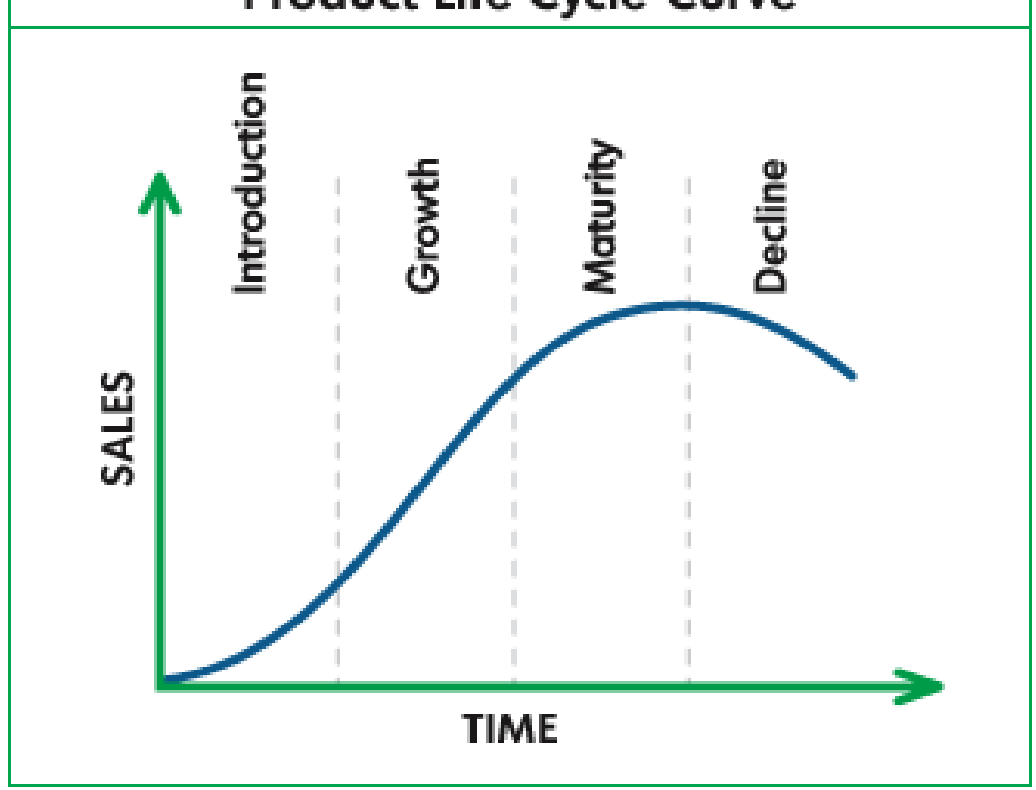

Gambar 3.

Tahap Dalam Daur Hidup Produk (Product Life Cycle)

\section{Introduction}

Pada fase ini penjualan akan tumbuh dengan lambat dan profit sangat kecil (bahkan mungkin mengalami kerugian) karena besarnya biaya yang dikeluarkan. Untuk itu perusahaan perlu mengeluarkan biaya promosi yang sangat besar (dibandingkan dengan tingkat penjualannya) yang ditujukan 
pada beberapa hal, seperti memberi informasi pada potential customer mengenai adanya produk baru (product awareness), biaya untuk mengeluarkan product trial, biaya distribusi barang. Perusahaan seharusnya memfokuskan produknya pada customer yang siap beli. Selain itu, pada fase introduction ini, biasanya harga barang yang ditawarkan cenderung tinggi. Akan tetapi produk yang ditawarkan adalah produk yang standar.

Perusahaan yang akan memperkenalkan produk baru harus membuat keputusan yang tepat kapan produknya akan memasuki pasar. Jika dia menjadi produk yang pertama (pioneer), maka hal ini akan memberikan pengaruh yang besar, akan tetapi resiko dan biaya yang ada juga cukup besar. Sebaliknya, jika dia menjadi produk pengikut (follower), maka produk ini akan menguasai pasar hanya apabila disertai dengan teknologi yang superior, kualitas yang baik, serta brand yang kuat.

Sebuah riset mengatakan bahwa produk yang pertama kali diperkenalkan di pasar (market pioneer) memperoleh pangsa pasar yang lebih besar dibandingkan dengan produk pengikut (follower). Bahkan ada riset lain yang mendapatkan bahwa 19 dari 25 perusahaan yang menjadi penguasa pasar di tahun 1923, tetap menjadi penguasa pasar di tahun 1983 (60 tahun kemudian). Hal ini dikarenakan customer akan menyebutkan brand dari produk tersebut ketika mereka puas dengan produk yang diberikan Akan tetapi, tidak selalu market pioneer menguasai pasar yang ada. Pada beberapa industri, justru follower mempunyai pangsa pasar yang lebih besar dibandingkan dengan pioneer. Sebuah riset mengatakan bahwa hal ini disebabkan oleh beberapa faktor seperti produk pioneer yang belum "matang", positioning yang salah, produk pioneer muncul saat demand masih lemah, biaya pengembangan produk yang menghabiskan dana yang dimiliki pioneer, kurangnya resource untuk bersaing dengan perusahaan lain yang lebih besar, serta kurangnya kompetensi dari manajemen pioneer. Sementara itu, kesuksesan follower ditunjang oleh harga produk yang lebih rendah, adanya peningkatan produk yang 
berkelanjutan, serta adanya pengambilan pangsa pasar dengan cara yang "kasar".

\section{Growth}

Pada fase ini pertumbuhan penjualan sangat pesat, sehingga profit yang diperoleh juga meningkat. Melihat opportunity yang ada, kompetitor-kompetitor baru mulai memasuki pasar. Mereka memperkenalkan produk yang sama dengan featurefeature yang berbeda serta distribusi yang lebih luas. Sejalan dengan adanya peningkatan demand, harga produk pun akan mangalami penurunan secara lambat (atau bisa juga harga tetap sama). Biaya promosi cenderung tetap atau jika mengalami peningkatan maka tidak akan drastis. Akan tetapi peningkatan biaya promosi ini tidak sebanding dengan peningkatan penjualan yang sangat tinggi.Untuk mempertahankan peningkatan pangsa pasar yang tinggi, perusahaan melakukan berbagai strategi:

- Meningkatkan kualitas produk, menambahkan feature baru dan memperbaiki desain produk, serta memberikan service tambahan atau jaminan terhadap produk

- Menambahkan model baru, ukuran baru, rasa baru, dan sebagainya untuk melindungi produk utama

- Memasuki segmen pasar baru

- Memperluas cakupan distribusi dan memasuki saluran distribusi baru

- Mengubah fokus advertising dari product awareness menjadi product preference

- Menurunkan harga jual produk untuk menarik second layer customer

\section{Maturity}

Fase ini biasanya berlangsung lebih lama dari fase-fase sebelumnya. Pada fase ini pertumbuhan penjualan cenderung lambat (bahkan dapat mulai menurun) karena produk sudah diterima oleh pasar. Profit biasanya akan stabil atau bahkan cenderung menurun karena adanya kompetitor. Tingkat penjualan yang menurun menyebabkan adanya kelebihan produksi, yang pada akhirnya berimplikasi pada persaingan. 
Untuk mendapatkan pasar, kompetitor melakukan berbagai hal, seperti meningkatkan promosi \& advertising, meningkatkan budget R\&D untuk pengembangan produk, dan sebagainya. Hal ini menyebabkan kompetitor yang lemah menjadi tersingkir. Supaya dapat tetap bersaing pada fase ini, ada beberapa strategi yang dapat dilakukan oleh perusahaan:

\section{- Market modification}

Perusahaan dapat meningkatkan pangsa pasarnya dengan 2 metode. Metode yang pertama yaitu dengan meningkatkan jumlah konsumen produknya. Hal ini dapat dilakukan dengan cara menarik konsumen produk pengganti (substitute product), memasuki segmen pasar baru, menarik konsumen produk kompetitor. Sedangkan metode yang kedua adalah dengan cara meningkatkan jumlah pemakaian produk. Konsumen diarahkan untuk menggunakan produk dengan frekuensi yang lebih sering, dengan takaran yang lebih banyak, atau menggunakan produk tersebut untuk kebutuhan yang lain.

\section{- Product modification}

Modifikasi produk dapat dilakukan melalui beberapa metode. Metode yang pertama yaitu dengan cara peningkatan kualitas, yang berarti peningkatan performa dari fungsi produk. Metode yang kedua yaitu penambahan feature, seperti ukuran, berat, material, aksesoris, dan sebagainya yang dapat meningkatkan fungsi, tingkat keselamatan, dan kenyamanan dari produk. Metode yang terakhir yaitu perbaikan desain (tingkat estetika) dari produk.

\section{- Marketing mix modification}

Untuk meningkatkan penjualan, perusahaan juga dapat melakukan analisis terhadap beberapa aspek, yaitu harga produk yang bersaing dengan kompetitor, distribusi yang lebih intensif, advertising yang menekankan pada brand differences, promosi penjualan, personal selling, dan juga service yang diberikan. Perusahaan seringkali bingung apakah lebih baik meningkatkan budget advertising atau budget promosi penjualan. Pada fase maturity, pengaruh promosi penjualan lebih besar dibandingkan dengan 
advertising karena konsumen produk mencapai titik ekuilibrium dalam kebiasaan membelinya dan dalam pilihannya. Dalam hal ini, pendekatan psikologi (advertising) kurang efektif dibandingkan dengan pendekatan finansial (promosi penjualan).

\section{Decline}

Pada fase ini penjualan akan menurun, sehingga profit juga akan semakin menurun. Penurunan penjualan ini dapat disebabkan oleh beberapa hal, seperti adanya perubahan teknologi, perubahan selera konsumen, serta semakin meningkatnya persaingan domestik maupun internasional. Pada fase ini, beberapa perusahaan akan meninggalkan pasar. Semakin kecil exit barriers, maka semakin mudah perusahaan untuk meninggalkan suatu industri. Sebenarnya, ini menjadi suatu hal yang menarik bagi perusahaan yang tetap bertahan pada industri tersebut, karena perusahaan tersebut dapat menarik konsumen dari perusahaan yang "pergi".

Berikut ini beberapa strategi yang dapat dilakukan oleh perusahaan yang berada pada fase decline:

- Meningkatkan investasi perusahaan untuk mendominasi pasar atau memperkuat posisi persaingan

- Mempertahankan level investasi perusahaan sampai pada titik dimana ketidakpastian terhadap industri menjadi jelas

- Mengurangi tingkat investasi perusahaan secara selektif dengan cara meninggalkan kelompok customer yang tidak memberikan keuntungan, serta meningkatkan investasi pada pasar yang memberikan keuntungan

- Mengambil investasi perusahaan untuk memperoleh dana cair (cash) dalam waktu yang singkat

- Meninggalkan bisnis dalam waktu yang singkat dengan cara menjual aset perusahaan secepatnya

Dalam memilih strategi yang tepat untuk dilakukan, perusahaan harus melihat kondisi industri yang ada serta kekuatan perusahaan untuk bersaing dalam industri tersebut. Jika kondisi industri sudah tidak menarik tetapi kekuatan perusahaan masih ada, maka sebaiknya perusahaan mempertimbangkan untuk meninggalkan industri tersebut. 
Sedangkan jika kondisi industri masih menarik dan perusahaan masih mempunyai kekuatan untuk bersaing, maka perusahaan dapat mempertimbangkan untuk meningkatkan investasinya.

\section{METODOLOGI PENELITIAN}

\subsection{Metode Penelitian}

Metode yang digunakan dalam penelitian ini adalah metode survei untuk memperoleh gambaran yang jelas mengenai objek yang diteliti. Materi yang disurvei adalah data umum responden, perilaku dan persepsi konsumen sebelum sosialisasi, serta mengetahui hasil sosialisasi terhadap perubahan persepsi konsumen. Langkah awal adalah mengumpulkan data dari responden melalui penyebaran kuesioner dengan cakupan wilayah kota Bogor dengan jumlah responden yang diteliti sebanyak 211 responden. Lokasi penelitian untuk penyebaran kuesioner adalah 5 pasar (tradisional) yang ada di wilayah Kota Bogor yaitu Pasar Bogor, Pasar Anyar, Pasar Gunung Batu, Pasar Yasmin, dan Pasar Jambu Dua. Kemudian langkah berikutnya adalah menyusun dan merekomendasikan suatu konsep strategi pemasaran dari hasil kuesioner untuk memasarkan minyak sawit merah.

\subsection{Jenis dan Sumber Data Penelitian}

Penelitian ini menggunakan sumber data yang berasal dari data primer dan data sekunder. Data primer berasal dari hasil kuesioner dan sumber data sekunder merupakan data empiris dan historis yang diperoleh dari studi pustaka dan digunakan sebagai data pendukung penelitian.

\subsection{Analisis Data}

Data yang diperoleh dianalisa dengan tahapan-tahapan sebagai berikut :

1. Analisis deskriptif, bertujuan untuk memperoleh gambaran secara mendalam dan objektif mengenai objek penelitian. Untuk membantu peneliti memaparkan hasil analisis maka informasi yang diperoleh akan disajikan dalam bentuk 
tabulasi, gambar maupun matriks sesuai dengan hasil yang diperoleh.

2. Analisis Fischbein; merupakan model pengukuran sikap yang berguna untuk mengukur keseluruhan atribut (multiatribut) suatu produk, dengan rumus :

di mana

$$
\text { Ao }=\Sigma(\text { bi })(\text { ei })
$$

Ao $=\quad$ sikap total konsumen terhadap produk tertentu.

$\mathrm{bi}=\quad$ kekuatan keyakinan konsumen terhadap atribut $\mathrm{i}$ dari produk "sebelum ia membeli atau menggunakannya".

ei $=\quad$ evaluasi kepercayaan konsumen terhadap atribut i dari produk secara umum, tanpa dikaitkan dengan merek tertentu. $\Sigma=$ penjumlahan dari sejumlah kriteria atribut i yang relevan.

3. Menyusun alternatif strategi pemasaran yang bisa dijadikan acuan guna memperkenalkan produk minyak sawit merah.

\subsection{Pelaksanaan Penelitian}

Pekerjaan dilaksanakan selama tiga bulan sejak bulan Juli tahun 2008 sampai dengan bulan September tahun 2008, dengan jadwal sebagai berikut:

Tabel 2

Jadwal Penelitian

\begin{tabular}{|c|c|c|c|c|c|c|c|c|c|c|c|c|c|}
\hline \multirow[t]{2}{*}{ No. } & \multirow[t]{2}{*}{ Pekerjaan } & \multicolumn{4}{|c|}{ Juli } & \multicolumn{4}{|c|}{ Agustus } & \multicolumn{4}{|c|}{ September } \\
\hline & & 1 & 2 & 3 & 4 & 1 & 2 & 3 & 4 & 1 & 2 & 3 & 4 \\
\hline 1. & Persiapan & & & & & & & & & & & & \\
\hline 2. & Numerasi & & & & & & & & & & & & \\
\hline 3. & Pelaksanaan Survey & & & & & & & & & & & & \\
\hline 4. & $\begin{array}{l}\text { Tabulasi data Analisis } \\
\text { Data }\end{array}$ & & & & & & & & & & & & \\
\hline 5. & Penyusunan laporan & & & & & & & & & & & & \\
\hline 6 & Pelaporan & & & & & & & & & & & & \\
\hline
\end{tabular}




\section{HASIL DAN PEMBAHASAN \\ 4.1. Identitas Responden}

Penelitian ini berguna untuk mengetahui sikap dan persepsi konsumen yang diperoleh melalui penyebaran kuesioner kepada 211 orang responden di wilayah Kota Bogor yaitu Pasar Bogor, Pasar Anyar, Pasar Gunung Batu, Pasar Yasmin, dan Pasar Jambu Dua. Penyebaran kuesioner dilakukan dengan cara random sampling dan hasil penyebaran kuesioner sebagai berikut.

\section{Jenis Kelamin}

Responden yang mengisi kuesioner dibedakan menurut jenis kelamin seperti terlihat pada gambar di bawah ini.

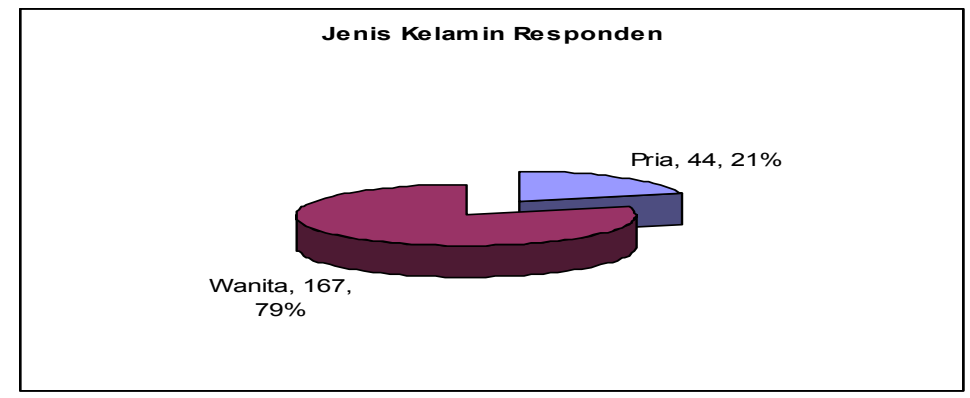

Gambar 4.

Jenis Kelamin Responden

Proporsi jenis kelamin antara pria dan wanita dari responden memperlihatkan bahwa responden wanita lebih banyak (79\%) daripada pria (21\%).

\section{Usia Responden}

Data responden berdasarkan usia dibedakan dalam lima kelompok usia seperti yang terdapat pada bagan serabi berikut: 


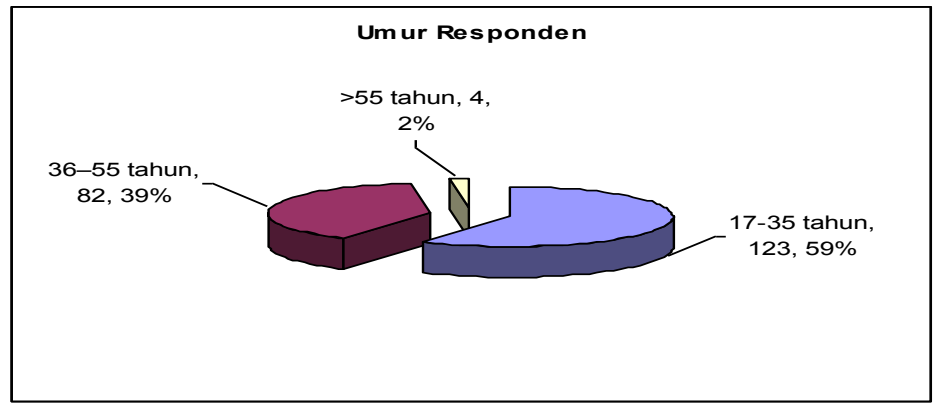

Gambar 5.

Umur Responden

Hasil analisis memperlihatkan bahwa kelompok usia 17-35 tahun (123 orang) merupakan responden terbanyak sebesar 59\% diikuti oleh kelompok usia 36-55 tahun (82 orang) dengan persentase $39 \%$.

\section{Tingkat Pendidikan}

Tingkat pendidikan responden pada penelitian ini terbagi dalam beberapa kategori yaitu SD, SMP, SMA, Diploma/Akademi, S1, dan S2. Rekapitulasi data yang diperoleh dapat dilihat pada gambar 6 berikut ini.

\section{Tingkat Pendidikan}

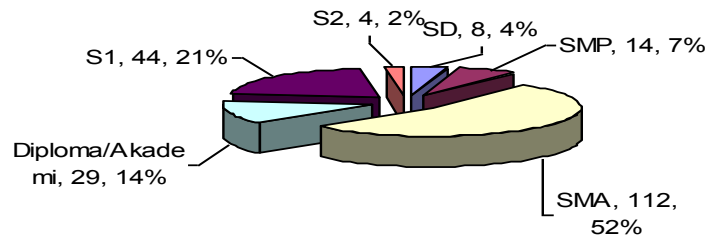

Gambar 6.

Tingkat Pendidikan Responden 
Hasil di atas menunjukkan secara umum bahwa tingkat pendidikan responden dalam penelitian ini adalah SMA sebesar 52persen diikuti oleh responden berpendidikan S1 sebesar 21persen.

\section{Status Perkawinan}

Dalam penelitian ini, status perkawinan responden dibagi ke dalam beberapa kelompok yaitu belum menikah, menikah, serta janda/duda. Jumlah dan persentase responden untuk masing-masing kelompok dapat dilihat pada gambar bagan serabi mengenai status perkawinan.

Hasil menunjukkan bahwa sebesar 57.82\% responden berstatus sudah menikah, dan dengan melihat pada gambar bagan serabi mengenai jumlah keluarga, tampak bahwa responden dengan status sudah menikah, memiliki jumlah anggota keluarga sebanyak 3-4 orang

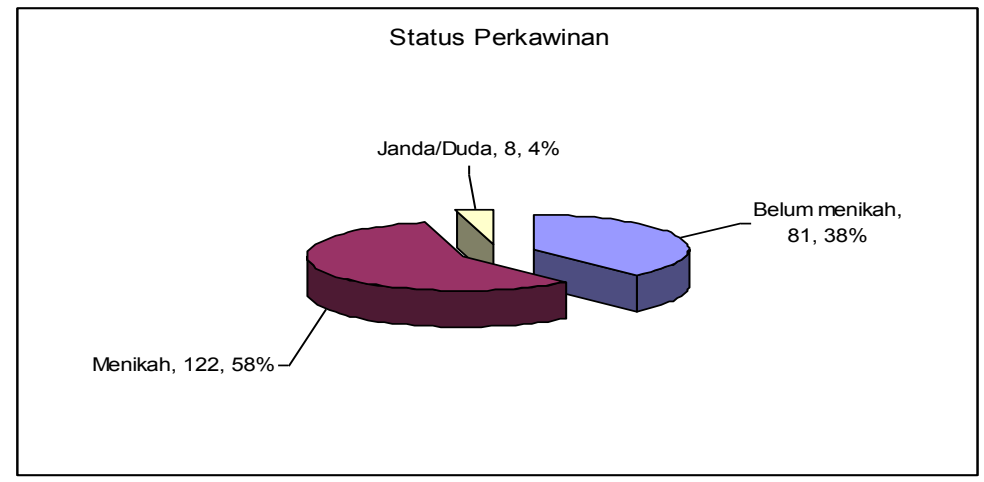

Gambar 7.

Status Perkawinan Responden

Melalui kuesioner penelitian pula dijaring informasi tentang jumlah anggota keluarga yang tinggal bersama seperti terlihat pada gambar 8 berikut ini. 


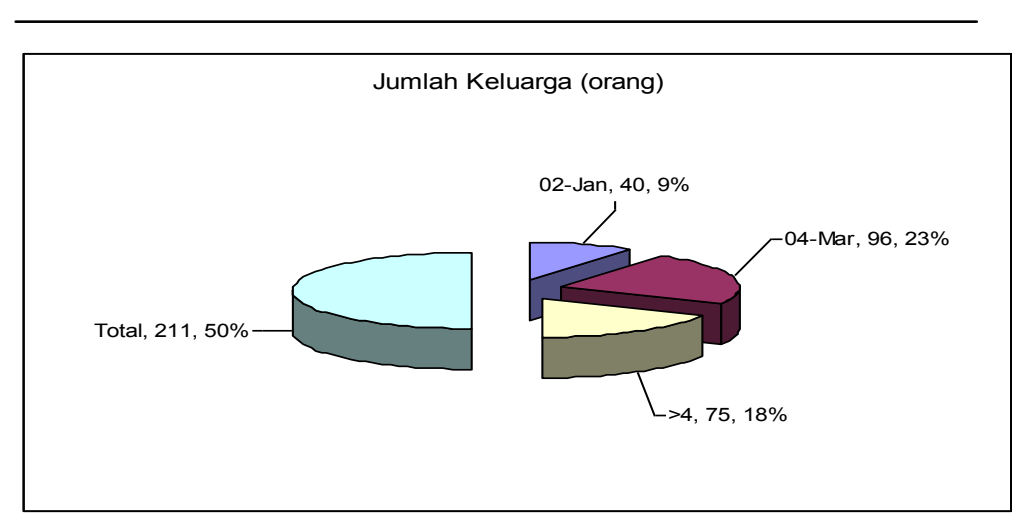

Gambar 8.

Jumlah Keluarga Responden

\section{Pekerjaan}

Dari sisi pekerjaan, menunjukkan bahwa sebanyak 59 orang atau $28.10 \%$ responden adalah ibu rumah tangga, kemudian 67 orang atau $31.90 \%$ adalah pelajar/mahasiswa, dan masing-masing sebesar $13.33 \%$ untuk PNS dan pegawai swasta. Secara jelas komposisi pekerjaan terlihat pada gambar 9 berikut ini.

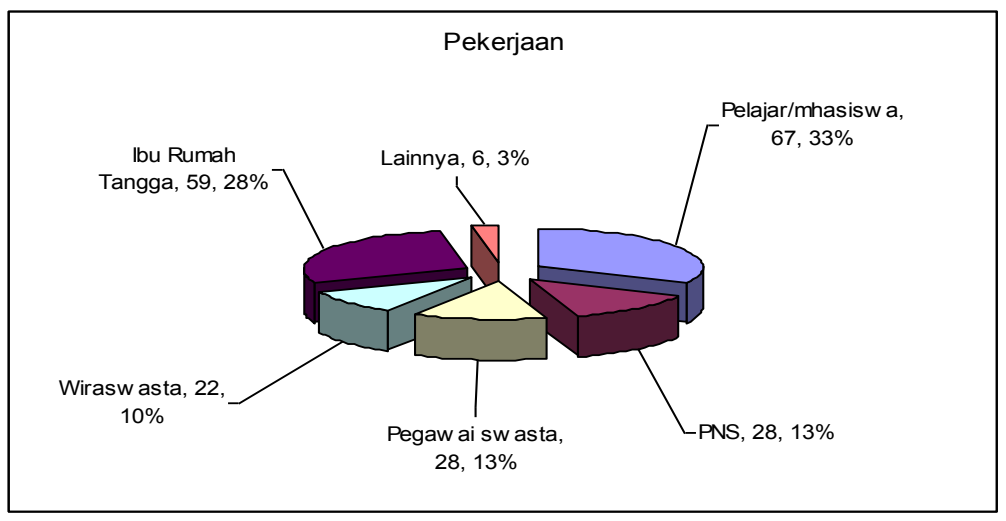

Gambar 9.

Pekerjaan Responden 


\section{Pengeluaran}

Berdasarkan hasil kuesioner dapat diketahui sebesar $24 \%$ menjawab pengeluran rutin mereka per bulan lebih besar dari Rp2.000.000,-; 19\% berkisar Rp1.500.000,- sampai dengan Rp2.000.000,- dan masing-masing 18\% responden mempunyai pengeluaran rutin Rp750.000,- sampai dengan Rp1.000.000,dan Rp1.000.000,- sampai dengan Rp1.500.000,-. Hal itu dapat dilihat pada gambar 10 berikut ini.

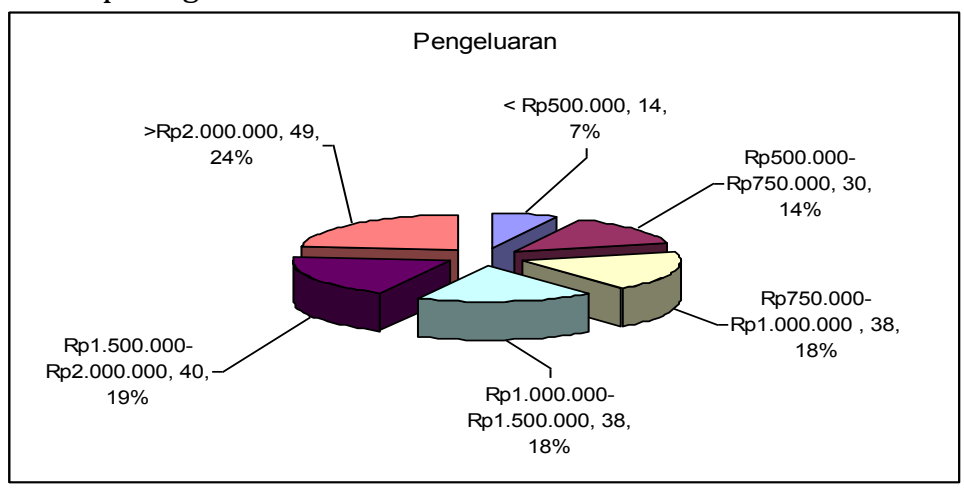

Gambar 10.

Pengeluaran Rutin per Bulan

\subsection{Industri Minyak Goreng}

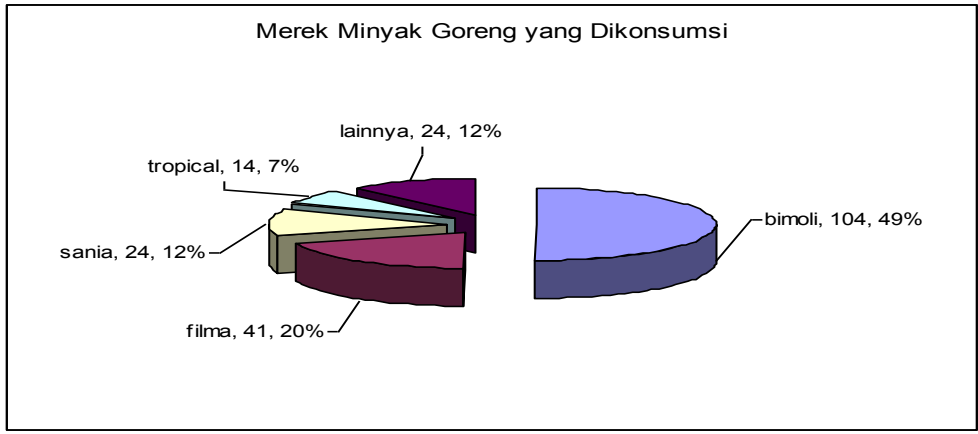

Gambar 11.

Merek Minyak Goreng Pilihan Konsumen 
Tabulasi pertanyaan terbuka mengenai merek minyak goreng yang paling sering dikonsumsi menunjukkan empat merek utama yang dipilih oleh lebih dari sepuluh persen responden. Pasar didominasi oleh minyak goreng merek Bimoli, sebesar 49\%, minyak goreng merek Filma sebesar 20\%, minyak goreng merek Sania sebesar 12\%, minyak goreng merek Tropical 7\%, sisanya jatuh ke kategori "lainnya" sebesar $12 \%$.

Hasil ini dapat menunjukkan bahwa struktur pasar minyak goreng adalah pasar bersaing, dengan nilai HerfindahlHirschman Index industri sebesar 3138 (kurang dari 5000) ${ }^{1}$, minyak goreng merek Bimoli merupakan market leader pada pasar ini.

Preferensi konsumen mengenai bentuk kemasan, sebagian besar memilih kemasan isi ulang (refill) yaitu 63\%, sementara sisanya memilih kemasan botol. Dasar dari pemilihan ini adalah harga kemasan isi ulang yang lebih murah dibandingkan dengan kemasan botol.

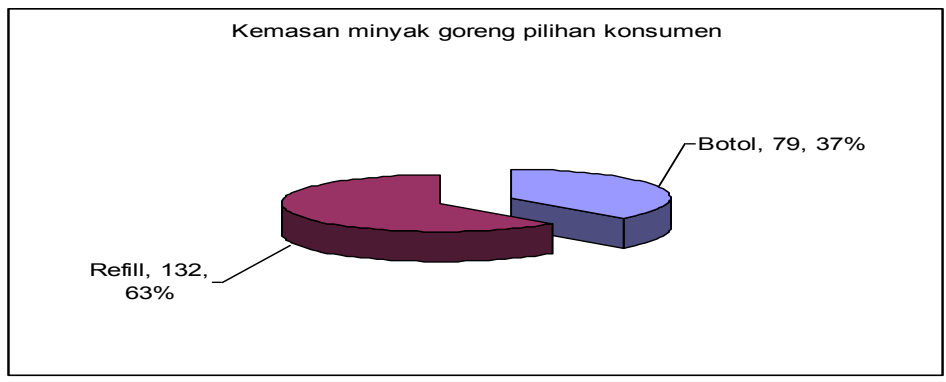

Gambar 12.

Kemasan Minyak Goreng Pilihan Konsumen

${ }^{1}$ Herfindahl-Hirschman Index berkisar dari 0 sampai 10000.

Semakin besar nilai indeks ini, industri semakin terkonsentrasi.

Nilai sebesar 10000 menunjukkan bahwa hanya ada satu perusahaan di dalam industri.. pasar berstruktur monopoli. Di atas 6000, oligopoly; antara $0.1 \mathrm{~s} / \mathrm{d} 5900$ struktur pasar adalah bersaing (Baye Michael R. Managerial Economics and Business Strategy 2003). 
Sebagian besar konsumen memilih ukuran kemasan satu liter dengan frekuensi pembelian dua kali sebulan. Kedua hal ini mendukung pernyataan sebelumnya terkait harga, secara implisit menunjukkan bahwa minyak goreng merupakan stapples good dengan sifat normal.

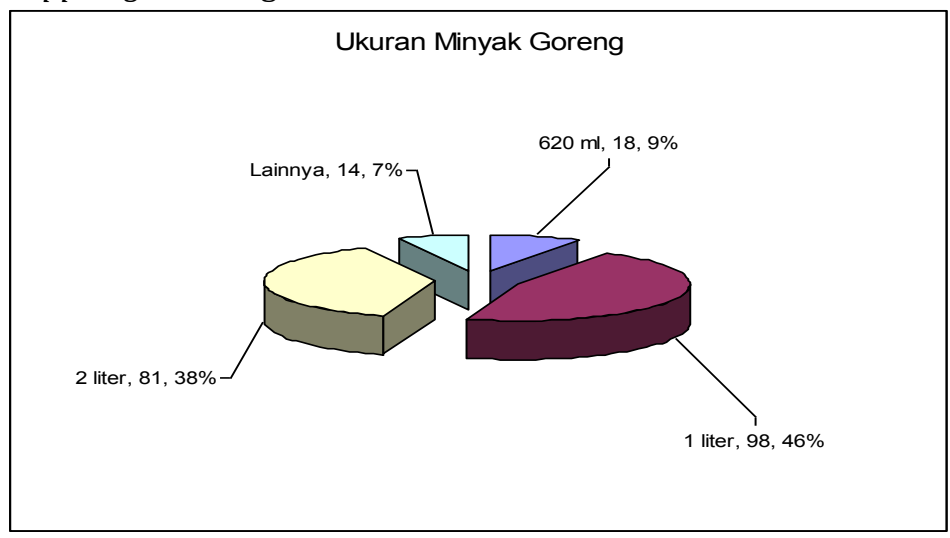

Gambar 13.

Ukuran Minyak Goreng Pilihan Konsumen

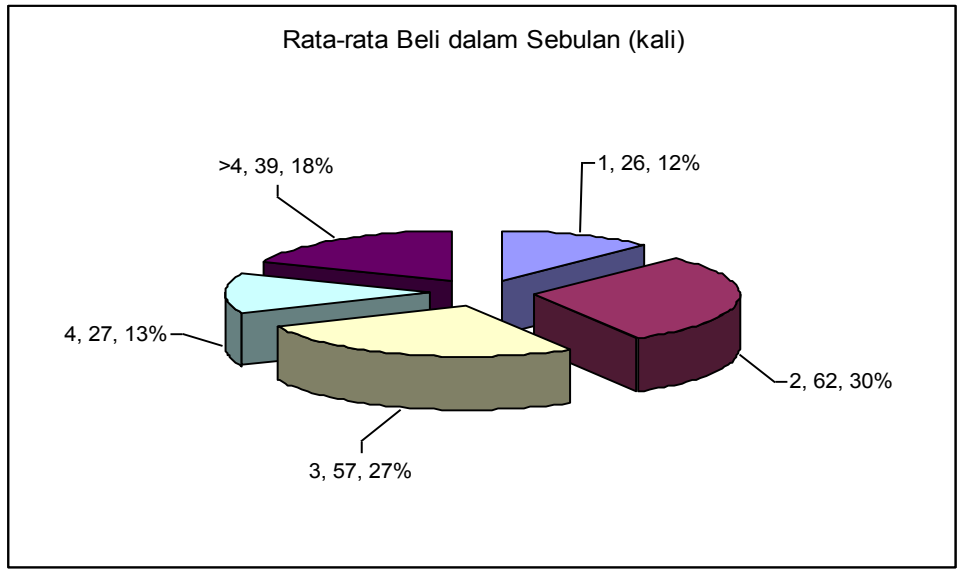

Gambar 14.

Frekuensi Pembelian Minyak Goreng 


\section{Attribute}

Dalam penelitian ini konsumen menetapkan kriteria atribut minyak goreng dalam kemasan, menunjukkan bahwa kualitas merupakan atribut terpenting. Disusul oleh kandungan nutrisi, manfaat untuk kesehatan dan harga. Hasil tersebut tampak pada gambar 15 di bawah ini.

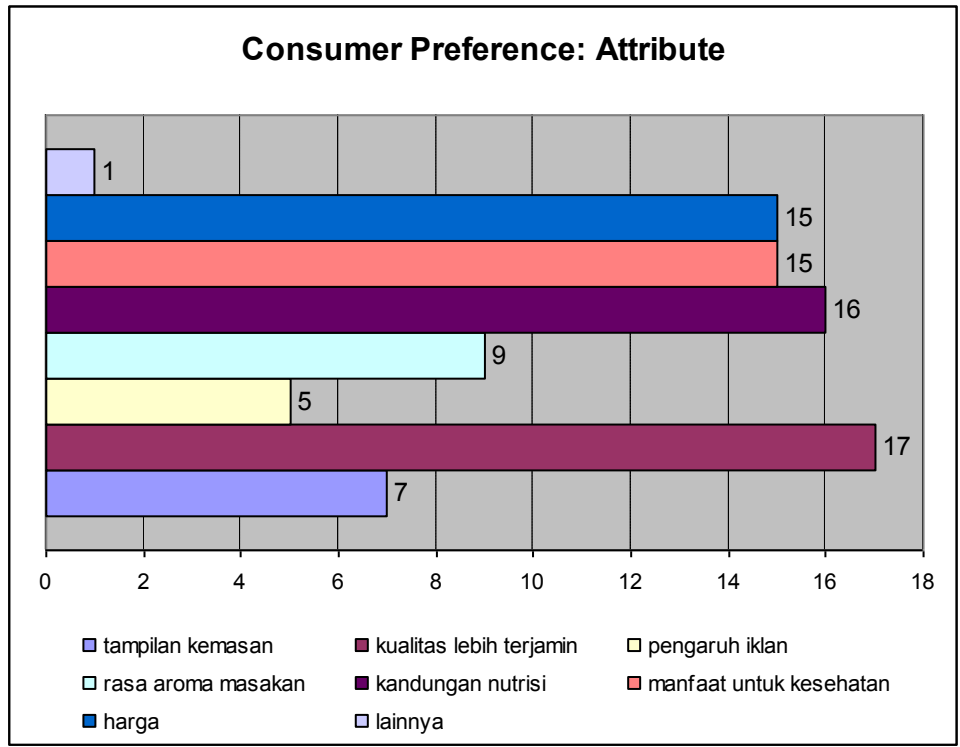

Gambar 15.

Preferensi Konsumen terhadap Atribut Minyak Goreng

Dari 211 responden, hanya 59 orang atau $27.96 \%$ yang pernah mengkonsumsi minyak goreng sawit merah. Untuk selanjutnya, persepsi dan sikap terhadap attribut minyak goreng sawit merah menggunakan 59 orang konsumen minyak goreng sawit merah ini.

Sumber informasi responden mengenai minyak goreng sawit merah terutama dari iklan $24 \%$, dari sumber lainnya sebesar 27\%, informasi dari supermarket/minimarket/warung sebesar $17 \%$, sumber informasi dari teman sebesar $14 \%$, sumber informasi dari pedagang sebesar 10\% dan sumber 
informasi dari keluarga juga sebesar 10\%. Dapat dijelaskan bahwa sumber informasi lainnya mengandung arti bahwa responden tidak mengetahui dengan pasti darimana responden memperoleh informasi tersebut. Dengan demikian, dapat diketengahkan sumber informasi efektif mengenai monyak goreng sawit merah ini berasal dari iklan. Namun, mengingat iklan minyak goreng sawit merah hampir tak pernah terdengar (bahkan dapat dikatakan tidak ada), kemungkinan responden memperoleh informasinya dari ulasan-ulasan di surat kabar atau majalah mengenai kesehatan, makanan sehat, atau ilmu pengetahuan populer.

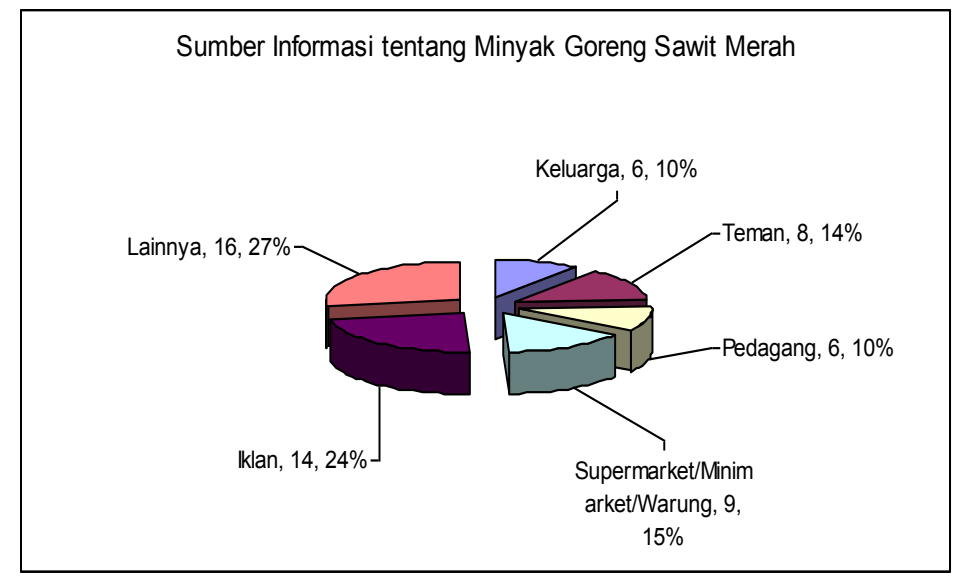

Gambar 16.

Sumber Informasi tentang Minyak Goreng Sawit Merah

\subsection{Persepsi dan Sikap terhadap Atribut Minyak Goreng Sawit Merah}

Persepsi dan sikap terhadap atribut minyak goreng yang baik dapat dilihat melalui nilai $\mathrm{A}_{0}$ (sikap total konsumen terhadap produk tertentu) yang merupakan perkalian bi (kekuatan keyakinan konsumen terhadap atribut i dari produk "sebelum ia membeli atau menggunakannya") dengan ei 
(evaluasi kepercayaan konsumen terhadap atribut i dari produk secara umum, tanpa dikaitkan dengan merek tertentu).

Kepercayaan konsumen terhadap minyak goreng sawit merah dapat dilihat dari Gambar 17 berikut ini.

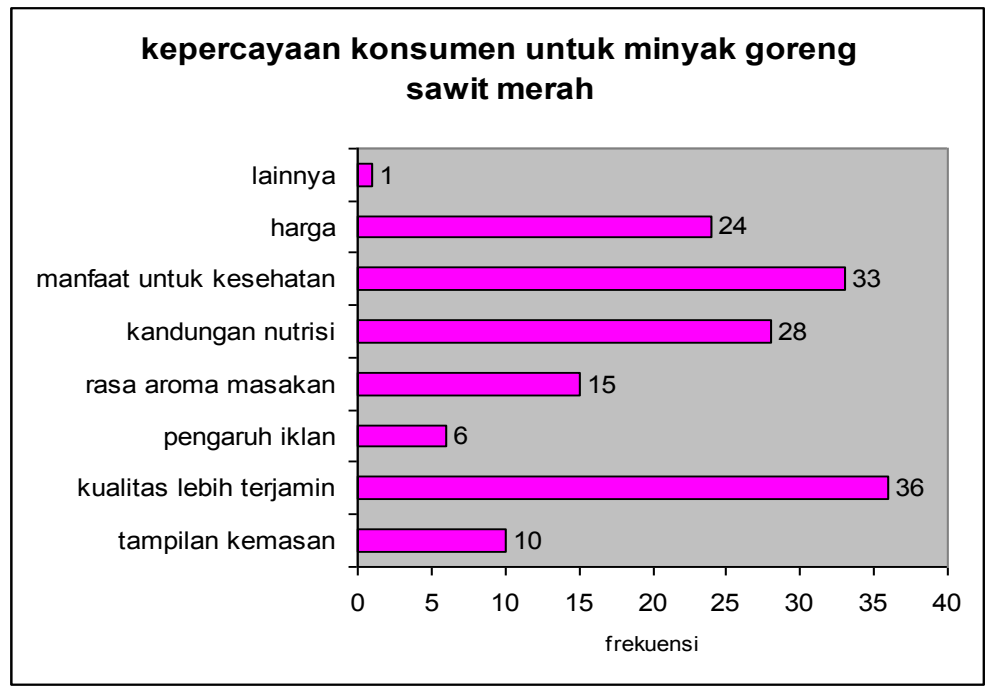

Gambar 17.

Kepercayaan Konsumen Minyak Goreng Sawit Merah

Dari nilai rata-rata sikap total konsumen terhadap minyak goreng sawit merah, tampak bahwa nilai probabilitas total yang diperoleh sebesar 20.1 masih kurang (berada pada pentile pertama skala Fischbein), menunjukkan respons terhadap minyak goreng sawit merah. Nilai minim dari probabilitas total terutama pada ketersediaan, kesediaan perusahaan, dan merek. Terkait dengan warna minyak goreng sawit merah yang dapat menyebabkan warna hasil gorengan agak kemerahan, umumnya responden tidak berkeberatan, karena kualitas lebih terjamin (nilai teknologi proses 51.9).

Dapat dikemukakan bahwa minyak goreng sawit merah sulit diperoleh, meskipun sebagian besar responden konsumen telah memahami manfaat minyak goreng sawit merah dibandingkan 
dengan minyak goreng sawit biasa. Belum adanya merek yang populer menunjukkan bahwa produk ini masih dalam tahap perkenalan. Untuk itu perlu diterapkan strategi pemasaran dalam tahap perkenalan.

Nilai Ao untuk minyak goreng sawit merah dapat terlihat pada tabel berikut:

Tabel 1.

Sikap Konsumen terhadap Minyak Goreng Sawit Merah

\begin{tabular}{|l|r|}
\hline \multicolumn{1}{|c|}{ Atribut } & \multicolumn{1}{c|}{ Ao } \\
\hline Manfaat Untuk Kesehatan & 52.9 \\
\hline Kejernihan Dan Warna & 20.8 \\
\hline Kandungan Kolesterol & 31.4 \\
\hline Kandungan Nutrisi & 47.5 \\
\hline Kandungan Bahan Pengawet & 9.66 \\
\hline Bentuk Kemasan & 8.28 \\
\hline Label & 13.4 \\
\hline Merek & 4.78 \\
\hline Rasa Dan Aroma & 20.8 \\
\hline Teknologi Proses & 51.9 \\
\hline Harga & 39.5 \\
\hline Ketersediaan & 1.41 \\
\hline Iklan & 5.08 \\
\hline Kesediaan Perusahaan & 1.32 \\
\hline \multicolumn{2}{|c|}{ Nilai Rata-Rata } \\
\hline
\end{tabular}

\subsection{Perumusan Topik Promosi Sosialisasi Minyak Sawit Merah Untuk Menunjang Pemasaran}

Pada tahap perkenalan, strategi yang perlu dilakukan adalah gain awareness, di mana produk hanya satu jenis, dengan strategi harga skimming atau penetapan harga penetrasi yaitu penetapan harga awal tertinggi yang dapat dijangkau konsumen. 
Strategi promosi yang terbaik pada tahap ini bersifat informasi dan mendidik sementara strategi tempat atau distribusi sebaiknya menggunakan saluran terbatas namun tidak "sangat terbatas" hingga konsumen mempertanyakan apakah sebenarnya produk yang bersangkutan ada. Biaya dalam tahap ini sangat tinggi, terkait biaya untuk mengeluarkan product trial, biaya distribusi barang. Sebaiknya upaya pemasaran difokuskan pada konsumen siap beli. Selain itu, meskipun pada tahap ini biasanya harga barang yang ditawarkan cenderung tinggi, namun sebaiknya pada minyak goreng sawit merah ini perlu dihindari, karena produk termasuk kategori stapples good yang bersifat standar.

Perusahaan yang akan memperkenalkan produk baru harus dengan tepat menetapkan kapan produknya akan memasuki pasar. Jika dia menjadi produk yang pertama (pioneer), maka hal ini akan memberikan pengaruh yang besar, akan tetapi resiko dan biaya yang ada juga cukup besar. Sebaliknya, jika dia menjadi produk pengikut (follower), maka produk ini akan menguasai pasar hanya apabila disertai dengan teknologi yang superior, kualitas yang baik, serta brand yang kuat.

Produk yang pertama kali diperkenalkan di pasar (market pioneer) memperoleh pangsa pasar yang lebih besar dibandingkan dengan produk pengikut (follower). Hal ini dikarenakan customer akan menyebutkan brand dari produk tersebut ketika mereka puas dengan produk yang diberikan Akan tetapi tidak selalu demikian, follower bisa mempunyai pangsa pasar yang lebih besar dibandingkan dengan pioneer. Hal ini disebabkan oleh beberapa faktor seperti produk pioneer yang belum "matang", positioning yang salah, produk pioneer muncul saat demand masih lemah, biaya pengembangan produk yang menghabiskan dana yang dimiliki pioneer, kurangnya resource untuk bersaing dengan perusahaan lain yang lebih besar, serta kurangnya kompetensi dari manajemen pioneer. Sementara itu, kesuksesan follower ditunjang oleh harga produk yang lebih rendah, adanya peningkatan produk yang berkelanjutan. 
Pada kasus minyak goreng sawit merah, kebijakan produk adalah produk standar, harga perlu lebih murah dari harga minyak goreng sawit jernih dengan saluran distribusi yang jelas. Topik promosi sosialisasi minyak sawit merah untuk menunjang pemasaran dapat difokuskan pada persepsi dan sikap konsumen terhadap minyak goreng sawit merah, yang tampak pada Gambar 18 di bawah ini.

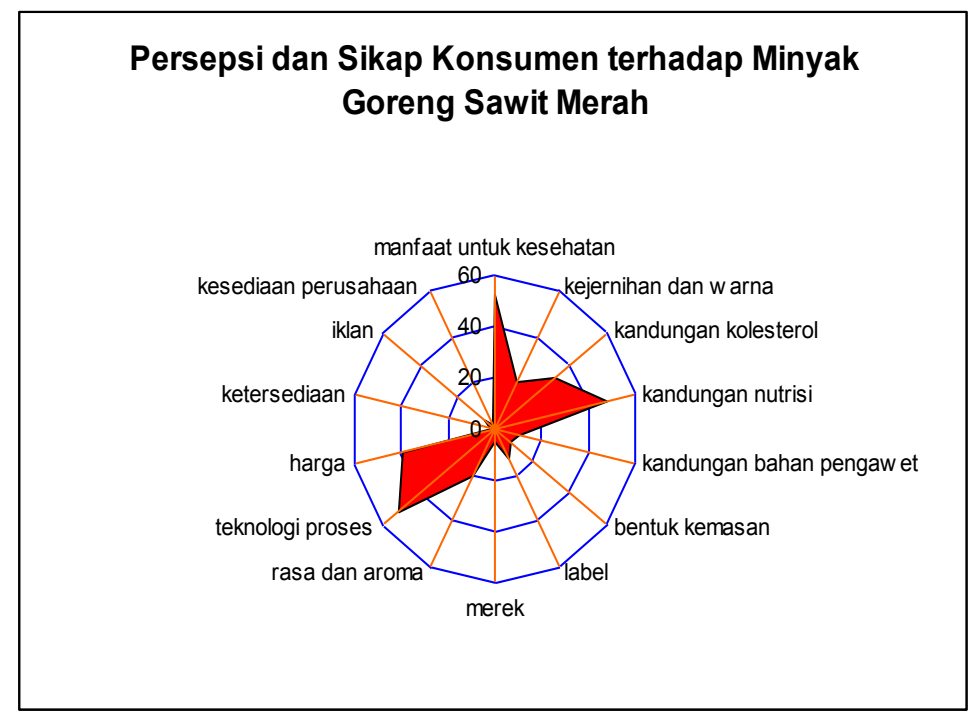

Gambar 18.

Persepsi Dan Sikap Konsumen Terhadap Minyak Goreng Sawit Merah

Berdasarkan hasil analisis, fokus sosialisasi sebaiknya adalah menjelaskan manfaat untuk kesehatan, teknologi proses produksi dan kandungan nutrisi Tak kalah penting adalah mengenai label dan harga, serta ketersediaan produk atau saluran pemasarannya. Media sosialisasi sebaiknya rubrikrubrik yang bersifat mendidik, baik berbentuk media televisi, radio maupun surat kabar. 


\section{KESIMPULAN DAN SARAN}

Hasil penelitian dapat menyimpulkan:

1. Masyarakat kurang paham mengenai minyak goreng sawit merah, dari 211 responden, hanya 59 atau 28 persen yang paham.

2. Industri minyak goreng berada dalam pasar bersaing, dengan leader Bimoli.

3. Preferensi masyarakat terhadap minyak goreng secara umum terutama terletak pada attribut kualitas (terkait proses produksi yang 'higienis'), kandungan nutrisi dan harga.

4. Persepsi masyarakat terhadap hasil olahan dengan menggunakan minyak goreng sawit merah menunjukkan tidak penting. Hal yang penting bagi masyarakat adalah kualitas dan kandungan gizi minyak goreng.

5. Persepsi dan sikap masyarakat terhadap minyak goreng sawit merah memperoleh skala Fischbein dalam pentil pertama, belum dikenal, atau berada pada tahap perkenalan siklus hidup produk. Diperlukan strategi pemasaran yang bersifat sosialisasi.

Berdasarkan hasil di atas, dapat disarankan beberapa hal, yaitu:

1. Strategi harga minyak goreng sawit merah, meskipun secara teori yang disarankan adalah skimming, namun karena minyak goreng sawit merah diharapkan menjadi substitusi minyak goreng yang merupakan stapples good, sebaiknya harga yang ditetapkan jauh di bawah minyak goreng biasa.

2. Strategi produk adalah menyediakan produk standar dengan kualitas baik dan kandungan nutrisi yang jelas, dalam arti memenuhi kriteria SII, bukan standar minyak goreng negara barat yang menyertakan kriteria kejernihan.

3. Strategi promosi yang sebaiknya diambil adalah yang bersifat informasi dan mendidik, yaitu sosialisasi. Topik yang dikemukakan sebaiknya terkait dengan kandungan dan proses produksi. Media yang diambil sebaiknya pada rubrik ilmu pengetahuan atau kesehatan berbentuk iklan layanan umu dengan frekuensi tinggi. 
4. Jalur distribusi yang diambil sebaiknya terbatas namun jelas dan pasti.

\section{Daftar Pustaka}

Adnan, M., Tranggono \& Pitoyo.1991. Kandungan tokoferol minyak sawit dan cara isolasinya. Prosiding Nilai Tambah Minyak Kelapa Sawit untuk Peningkatan Derajat Kesehatan, Jakarta.

Bakrie, A. 1998. Trilyunan rupiah per tahun nilai komponen aktif alami dalam minyak sawit terbuang percuma. Makalah Seminar Nasional Minyak Sawit dan Penelitian, Jakarta, 24 Pebruari.

Gordon, T. 1977. High density lipoprotein as a protective factor against coronary heart disease. The American Journal of Medicine. 62 :707-14.

Iwashaki, R. \& M. Murokoshi. 1992. Palm oil yields - carotene for world market oleochemicals. Inform, vol 3 No 2, 210-217.

Maulida, D. 2007. Kebijakan ekspor impor untuk mendukung pengembangan industri minyak kelapa sawit. Pros. Sem. Nas. Strategi Pengembangan dan Kebijakan Pendukung Industri Kelapa Sawit Nasional. BPPT, Jakarta, 18-19 Juli.

Muchtadi, T.R.M.1998. Peranan komponen aktif minyak sawit untuk kesehatan. Makalah Makalah Seminar Ilmiah Minyak Sawit Potensi dan Prospek Nilai Gizi serta Komponen Aktif Minyak Sawit dalam Mendukung Kesehatan Masyarakat. Pusat Studi Pembangunan Lembaga Penelitian, IPB. Jakarta, 24 Pebruari.

Muhilal, 1991. Minyak sawit, suatu produk nabati untuk penanggulangan atherosclerosis \& penundaan proses 
penuaan. Prosiding Seminar Nilai Tambah Kelapa sawit untuk Derajat Kesehatan. Jakarta.

Puspitasari, N. L., D. R. Adawiyah, S. S. Samiaji, A. Purbowo. 1998. Pengaruh penggorengan terhadap mutu minyak sawit merah. Makalah Poster Hasil Penelitian Potensi dan Prospek Nilai Gizi serta Komponen Aktif Minyak sawit dalam mendukung Kesehatan Masyarakat. Pusat Studi Pembangunan - Lembaga Penelitian, IPB. Jakarta, 24 Pebruari.

Rimbawan \& E. Damayanti. 1998. Potensi pemanfaatan minyak sawit merah sebagai sumber ?-karoten pada beberapa produk pangan. Makalah Poster Hasil Penelitian Potensi dan Prospek Nilai Gizi serta Komponen Aktif Minyak sawit dalam mendukung Kesehatan Masyarakat. Pusat Studi Pembangunan - Lembaga Penelitian, IPB. Jakarta, 24 Pebruari.

Rossell, J.B. (NY). Frying Improving Quality. Woodhead Publishing Limited, $\mathrm{p}$ 148. Taken from http://books.google.co.id./ , 27 May 2008

Shawn A. Butler and Paul Fischbeck, Multi-Attribute Risk Assessment, CMU Ed., 2007 